\title{
Farmer Perceptions and Preferences to Shallot Farming Technology Introduction in Grobogan District, Central Java, Indonesia
}

\author{
Dewi Sahara ${ }^{1, *}$, Aryana Citra Kusumasari ${ }^{1}$ and Agus Hermawan ${ }^{1}$ \\ Central Java Assessment Insitute for Agriculture Technology (AIAT)
}

\begin{abstract}
Farmers commonly use seed bulbs in shallot farming. Therefore it is required to conduct a demonstration plot to promote the technology of true shallot sheet (TSS). The study aims to determine the performance of the newly seedling technique and determine the perceptions and preferences of farmers towards shallot farming, in Padang Village, Tanggungharjo SubDistrict, Grobogan District, in September - November 2018. The study used a demonstration plot of shallot farming using seedling and survey methods to the 30 shallots farmers. Financial analysis (BCR and MBCR) was used to determine the performance of shallot farming, while farmers' perceptions and preferences were analyzed descriptively with scoring techniques. The results showed that even though the cost of shallot farming using seedling was higher, it resulted in higher production (BCR 2.76 vs 0.25). The TSS using as planting material against bulbs was also beneficial since the MBCR value was 5.64, implying that the seedling technique was more profitable than seed bulbs using. With these significant results, farmers stated a high perception of shallot farming using seedling, indicated a high level of preference, which is $73.33-93.33 \%$. Based on these results, the government should widely disseminate the TSS to shallot farmers.
\end{abstract}

\section{Introduction}

Shallot is one of the horticulture commodities that have high economic value. Indonesian households consume daily shallot commodities. Therefore, the demand for the shallot increases along with population growth and the fast development of the shallots' food industry. The huge market for shallot opens up opportunities to intensify its cultivation as a source of income and employment opportunities for regional economic development.

Central Java is the largest shallot production center in Indonesia, with a production of 445,585 tons and has first ranks in national production with a contribution of $29.64 \%$ [1]. Shallot production center in Central Java locates in Brebes Regency with production in 2018 of 290,564 tons with a contribution of $65.21 \%$ [2]. The shallots' cultivation has spread in all districts in Central Java. One of which is Grobogan District. In 2018 the production of this district was 12,328 tons and contributed $2.77 \%$ to the output of shallots in Central Java.

* Corresponding author: dewisahara.ds@gmail.com 
Farmers commonly use bulbs as planting material since it is more practical with a high success rate. However, continuous use of bulbs from the same variety might cause a lower chance of improving the quality of the product [3]. It also lowered the competitiveness and productivity of Indonesian shallots $[4,5]$.

Instead of using bulbs, the development of shallot farming can make use of botanical seeds (True Shallot Seed/TSS). TSS is a new technology that developed in the early 1990s, and superior varieties of TSS from the Vegetable Research Institute have been obtained and offered. The use of TSS has several advantages over seed bulbs. First, the total TSS requirement is lower, which is only $3-4 \mathrm{~kg}$ per hectare compared to the need for seed tubers of 1.5-2.0 tons per hectare [6;7]. The transportation of TSS is more comfortable and cheaper [8]. It also produces healthier plants because TSS is pathogen-free and produces better quality bulbs [9]. However, the age of seedlings harvested from TSS is 19-26 days longer than the period of harvest using seed bulbs [10].

The use of TSS in Central Java began in 2014 in Grobogan District. Although the development of TSS at the farm level is still limited and has not been widely spread, this is due to several constraints faced by farmers. Farmers are facing transition constraints of the adaptation of cultivation techniques from bulbs using to seeds (TSS). TSS using requires a longer time in the nursery and needs maintenance persistence.

Farmers are the main actors in shallot farming. Therefore their perceptions and preferences have an essential role in farming development. Farmers' perception of the shallot planting material using is significant since it is being the basis for making decisions to accept or reject the innovation. If the characteristics of innovation are following the expected farmers' perception, the innovation will be easily recognized. Conversely, the farmers will reject the innovation if the perception of innovation is not accord [11]. Therefore it is necessary to study farmers' perceptions and preferences in shallot cultivation as a basis for scaling up/disseminating the new technologies. This study aims to: 1) determine the performance of shallot farming, and 2) determine the perceptions and preferences of farmers towards shallot farming using seed bulbs or TSS.

\section{Methodology}

\subsection{Site and Time of Study}

The study site is located in Padang Village, Tanggungharjo Sub-District, Grobogan District, in September - November 2018. The determination of the study site purposively chosen with the consideration that Grobogan District was one of the shallot development areas in Central Java.

\subsection{Method of the Study Implementation}

The implementation of the study used a demonstration plot of shallot farming using TSS (seedling) covering an area of 1 hectare of farmer's land. The study compared the performance of the newly cultivation technique to the existing shallots cultivation farming, which using bulbs seeds. The source of data of existing farming performance was collected by conduct observation and survey to farmers. Table 1 presents the differences in technology components of shallot farming using seedling and bulbs. 
Table 1. Technology Component of Shallot Farming in Padang Village, Tanggungharjo Sub-District, Grobogan District, 2018

\begin{tabular}{|c|l|l|l|}
\hline \multirow{2}{*}{ No } & \multicolumn{1}{|c|}{ Component of } & \multicolumn{2}{c|}{ Shallot Farming Technology } \\
\cline { 2 - 4 } & \multicolumn{1}{|c|}{ Technology } & \multicolumn{1}{c|}{ Seedling } & Seed Bulbs \\
\hline 1. & Planting material & Bima Brebes & Bima Brebes \\
\hline 2. & Varieties & $\begin{array}{l}\text { Sowing seeds in the } \\
\text { planting medium up to 45 } \\
\text { days }\end{array}$ & $\begin{array}{l}\text { Not sown/directly } \\
\text { planted }\end{array}$ \\
\hline 3. & Nursery techniques & $\begin{array}{l}\text { Specific location-based on } \\
\text { soil analysis }\end{array}$ & Farmers' habits \\
\hline 4. & Fertilization & $\begin{array}{l}\text { Use biological agents and } \\
\text { selective pesticides }\end{array}$ & $\begin{array}{l}\text { Using chemical } \\
\text { pesticides }\end{array}$ \\
\hline 5. & Pest control &
\end{tabular}

In the demonstration plot of shallot farming, which using seeds or TSS, the seeds sown in the nursery with media composed of soil, manure, and husk charcoal in a ratio of 1: 1: 1. After 45 days after seeding, the seeds transplanted into the land.

Seeds planted in a spacing of $10 \times 10 \mathrm{~cm}$ and three seedlings per planting hole. Fertilization dosage based on the results of laboratory analysis of soil samples, i.e., 20 tons per hectare of organic fertilizer, $533 \mathrm{~kg}$ of Phonska, 66 kilograms of $\mathrm{KCl}, 200$ kilograms of ZA, 200 kilograms of $\mathrm{KNO}_{3}$, and 400 kilograms of NPK Mutiara. Pest and disease controlling use selective chemical of pesticides.

\subsection{Data Collection}

The data collected is primary and secondary. Primary data were collected from pilot shallot farming using seedling and survey methods of 30 shallot farmers. The types of primary data collected include : 1) input and output data of shallot farming, 2) farmers' perceptions of the use of seedling and seed bulbs, and 3) farmers' preferences on technology components of shallot farming using seedling.

\subsection{Data Analysis}

\subsubsection{Determination of the performance of TSS and seed bulbs}

Determination of the performance of TSS and seed bulbs, the data were analyzed descriptively using the average value of each technology component. The economic feasibility of each technology, the following financial analysis $[12 ; 13 ; 14]$ apply:

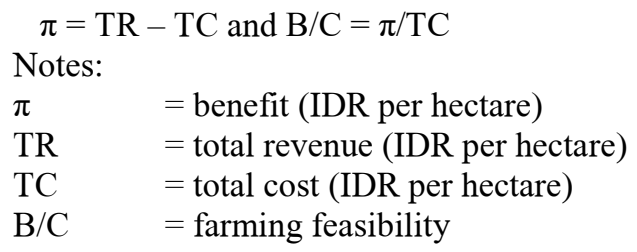

Furthermore, to determine the level of feasibility of farming due to technological changes from seed bulbs to TSS/seedling, losses and gains analysis through marginal benefits and costs were utilized, with the below formula [15] : 


$$
\text { MBCR }=\frac{\text { The farming benefit of seedling }- \text { Farming benefit of seed bulbs }}{\text { Cost of seedling - Cost of seed bulbs }}
$$

If $\mathrm{MBCR}=1$, the seedling technology does not provide an increase in revenue or additional income equals additional costs, if $\mathrm{MBCR}<1$ means additional revenue from the seedling technology is less than the extra cost, and if MBCR $>1$ income from the seedling technology is higher than the additional cost.

\subsubsection{Analysis of farmers' perceptions}

Analysis of farmers' perceptions uses ordinal data with scoring techniques. The scoring technique was also used by [11]. They measured the level of farmers' perceptions of true shallot seed technology in Sigi District, Central Sulawesi. The ordinal data obtained are then analyzed descriptively.

There are two farmers' perceptions of the demonstration technology of shallot farming, in which seedling and seed bulbs. The assessment makes use of 13 indicators. i) how farmers get shallot seedling/bulbs, ii) price of seedling/bulbs, iii) timeliness of obtaining seedling/ bulbs, iv) suitability of varieties, v) ease of planting, vi) ease of growth, vii) use of labor, viii) size of bulbs, ix) color of bulbs, x) aroma of the bulbs, xi) selling price, xii) costs and xiii) profits. Determination of the average score of each statement and the interval scale used the following formula:

Average score $=$ total score/number of respondents

Interval scale $=($ highest value - lowest value $) /$ number of interval scales

There are three classes of farmers' perceptions of shallot farming technology, namely high, medium, and low. The scale of perception determines the number of indicators. The lowest value (1) and the highest value (5) are multiply with 13 indicators. The results obtained are 13 for the lowest value and 65 for the highest value; therefore, the interval scale obtained is 17.3. Based on these values, the criteria for perception level are: 1) low perception (scale 13.0 - 30.3), 2) medium perception (scale 30.4 - 47.7), and 3) high perception (scale $47.8-65.0$ ). The performance of farmers' perceptions of shallot farming indicators makes use of the Perceptual Mapping technique, i.e., by making a spider web chart of the sum value in the form of a two-dimensional graph.

\subsubsection{Evaluation of farmers' preferences of farming technology innovation}

Evaluation of farmers' preferences of farming technology innovation carried out by getting data/information for the introduction of seedling in shallot farming. The data collected is ordinal data using scoring techniques, which is analyzed descriptively using percentage values.

\section{Results and Discussions}

\subsection{Shallot Farming Performance}

Shallot farming in Padang Village, Tanggungharjo Sub-District, Grobogan District, is considered as the central farming for 86.67 percent of respondents. The remaining (13.3 percent) of respondents have rice farming as their main farming. However, farmers 
cultivate shallot in a relatively small area of land (around 0.29 hectares). To fulfill the household expenditures, most of the respondents also have other jobs such as traders, carpenter, service providers, and other businesses.

Most of the shallot farmers need $1,200 \mathrm{~kg}$ per hectare of seed bulbs for planting material. Farmers use various both in number and types of fertilizers. Considering the high amount of shallot bulbs as seeds, [16] suggests that farmers produce their seeds by selecting bulbs from healthy yields that are free from infection of seed-borne diseases and have passed two months dormancy. The proportion of seed bulbs purchases is still higher than seedling/TSS purchases, which are $58.73 \%$ or $77.50 \%$ from the total farm costs and is being the highest proportion of shallot farm costs (Table 2).

Table 2. Use of Production Inputs and Costs per Hectares of Shallot Farming in Padang Village, Tanggungharjo Sub-District, Grobogan District, 2018

\begin{tabular}{|c|c|c|c|c|c|}
\hline \multirow[t]{3}{*}{ No. } & \multirow[t]{3}{*}{ Description } & \multicolumn{4}{|c|}{ Planting Material } \\
\hline & & \multicolumn{2}{|c|}{ Seedling } & \multicolumn{2}{|c|}{ Seed Bulbs } \\
\hline & & Volume & Cost (IDR) & Volume & Cost (IDR) \\
\hline 1. & $\begin{array}{l}\text { Planting material (plant, } \\
\mathrm{kg} \text { ) }\end{array}$ & 510,000 & $\begin{array}{r}51,000,000 \\
(58.73)\end{array}$ & 1.200 & $\begin{array}{r}36,000,000 \\
(77.50)\end{array}$ \\
\hline \multirow[t]{9}{*}{2.} & Fertilizers: & & & & \\
\hline & $\begin{array}{lll}\text { a. } & \begin{array}{l}\text { Organic } \\
(\mathrm{kg})\end{array} & \text { fertilizer }\end{array}$ & 20,000 & $\begin{array}{r}10,000,000 \\
(11.52)\end{array}$ & 300 & $\begin{array}{r}150,000 \\
(0.32)\end{array}$ \\
\hline & b. Urea $(\mathrm{kg})$ & - & - & 70 & $\begin{array}{r}126,000 \\
(0.27)\end{array}$ \\
\hline & c. SP-36 (kg) & 111 & $222,000(0.26)$ & 300 & $\begin{array}{r}600,000 \\
(1.29)\end{array}$ \\
\hline & d. Phonska (kg) & 533 & $1,225,900(1.41)$ & 500 & $\begin{array}{r}1,150,000 \\
(2.48)\end{array}$ \\
\hline & e. ZA (kg) & 200 & $280,000(0.32)$ & - & - \\
\hline & $\begin{array}{ll}\text { f. } & \mathrm{KCl}(\mathrm{kg}) \\
\end{array}$ & 66 & $462,000(0.53)$ & - & - \\
\hline & $\begin{array}{ll}\text { g. } & \mathrm{KNO} 3(\mathrm{~kg}) \\
\end{array}$ & 200 & $6,000,000(6.91)$ & - & - \\
\hline & h. NPK Mutiara $(\mathrm{kg})$ & 400 & $4,400,000(5.07)$ & - & - \\
\hline \multirow[t]{3}{*}{3.} & Pesticides : & & & & \\
\hline & a. Liquid (liter) & 10 & $2,000,000(2.30)$ & 14 & $\begin{array}{r}2,800,000 \\
(6.03)\end{array}$ \\
\hline & b. Powder $(\mathrm{kg})$ & 5 & $1,250,000(1.44)$ & 2.5 & $\begin{array}{r}625,000 \\
(1.35)\end{array}$ \\
\hline \multirow[t]{2}{*}{4.} & Labor (man days) & 200 & $\begin{array}{r}10,000,000 \\
(11.51)\end{array}$ & 100 & $\begin{array}{r}5,000,000 \\
(10.76)\end{array}$ \\
\hline & Total Cost & & $86,839,900$ & & $46,451,000$ \\
\hline
\end{tabular}

Note: Numbers in parentheses are a percentage of total costs

Source: Primary data, 2018 (processed)

The second-largest cost of seedling - shallot farming is fertilization costs, which reach $26.01 \%$. The fertilizer type and dosage used is by the results of soil analysis to obtain location-specific fertilization-meanwhile, fertilizer cost for bulbs-shallot farming placed in the fourth rank. The most significant proportion of expenditure after seed bulbs is labor wages, reaching $10.76 \%$ of the total farm costs. These results are in line with [17] research. The highest expenditure on shallot farming in Central Lampung is used to buy seed bulbs, followed by fertilizer costs and labor costs. In farmer technology, the highest proportion of costs was on purchasing seed bulbs, followed by wages labor, and fertilizer costs. [18] stated that the purchase cost of shallot bulbs in Gana is very high and some farmers use the harvest to be planted in the next planting season. 
Entire labor using between seedling farming and seed bulbs differ 100 man-days. The difference is due to differences in transplanting of seedling, which requires a longer time than the planting of bulbs and differences in the length of maintenance time. The harvest time of seedling shallots takes 19-26 days longer than planting with seed bulbs.

Shallot yield of seedling was $32,580 \mathrm{~kg}$ per hectare, while the production of bulbs shallot farming was 5,800 kilograms per hectare. It means the two systems differ in production as much as 26,780 kilograms per hectare (Table 3). The product obtained in this study is higher than the yield of TSS in the Sigi District, Central Sulawesi, which was $14,900 \mathrm{~kg}$ [13]. Different spacing arrangements caused the difference in production, i.e. seedling is planted more closely with a spacing of $10 \times 10 \mathrm{~cm}$, while seed bulbs cultivate in a spacing of $10 \times 15 \mathrm{~cm}, 15 \times 15 \mathrm{~cm}$, or $15 \times 20 \mathrm{~cm}$. The difference in planting distance causes differences in plant population, resulting in different production levels. [19] suggested that production is directly influenced by the plant population, the larger the population, the higher the production.

Table 3. Production and Profit per Hectare of Shallot Farming in Padang Village, Tanggungharjo Sub-District, Grobogan District, 2018

\begin{tabular}{|c|l|r|r|}
\hline \multirow{2}{*}{ No } & \multicolumn{1}{|c|}{ Description } & \multicolumn{2}{|c|}{ Planting material } \\
\cline { 3 - 4 } & & \multicolumn{1}{c|}{ Seedling } & Seed Bulbs \\
\hline 1. & Yield (kg) & 32,580 & 5,800 \\
\hline 2. & Yield Value (IDR) & $325,800,000$ & $58,000,000$ \\
\hline 3. & Cost (IDR) & $86,839,900$ & $46,451,000$ \\
\hline 4. & Profit (IDR) & $238,960,100$ & $11,549,000$ \\
\hline & BCR & 2.75 & 0.25 \\
\hline & MBCR & \multicolumn{2}{|c}{5.63} \\
\hline
\end{tabular}

Source: Primary data, 2018 (processed)

At the price level of IDR 10,000 per $\mathrm{kg}$, the profit received by farmers from shallot farming with seedling was IDR 238,960,100, much higher than the bulbs shallot farming which was only IDR $11,549,000$. [20] stated that using TSS as a planting material significantly increased productivity and profits up to 70 million rupiahs from one planting season. Therefore the ratio between profit and cost or BCR of each farming was 2.75 and 0.25 , respectively. These positive BCR results indicated that farmers could develop shallot farming both with seedling and with bulbs. The BCR value obtained was lower than the BCR value of the seed bulbs technology in Balochistan, namely 1.30 [21].

Farmers might obtain additional benefits if they change their shallot planting materials from seed bulbs to a seedling. Even though these changes increase farming costs by IDR $40,388,900$ (86.95\%), farmers might gain additional profit up to IDR 227,411,100 $(489,575 \%)$ compared to the seed bulbs of shallot application. Moreover, changes in planting material using have an $\mathrm{MBCR}$ value $=5.63$. This value means that every additional cost of IDR 100,000 provides an extra profit of IDR 563,000. Meaning to say, additional profits received by farmers are still higher than the expenses of shallot farming. Therefore shallot seedling could be economically applied by farmers.

\subsection{Farmers' Perception of Shallot Farming}

Figure 1 presents farmers' perceptions of a demonstration plot of seedling and seed bulbs shallot farming. High perceptions indicate farmers have good perceptions, medium perceptions indicate farmers have normal perceptions while low perceptions indicate farmers have poor perceptions against specific indicators. 


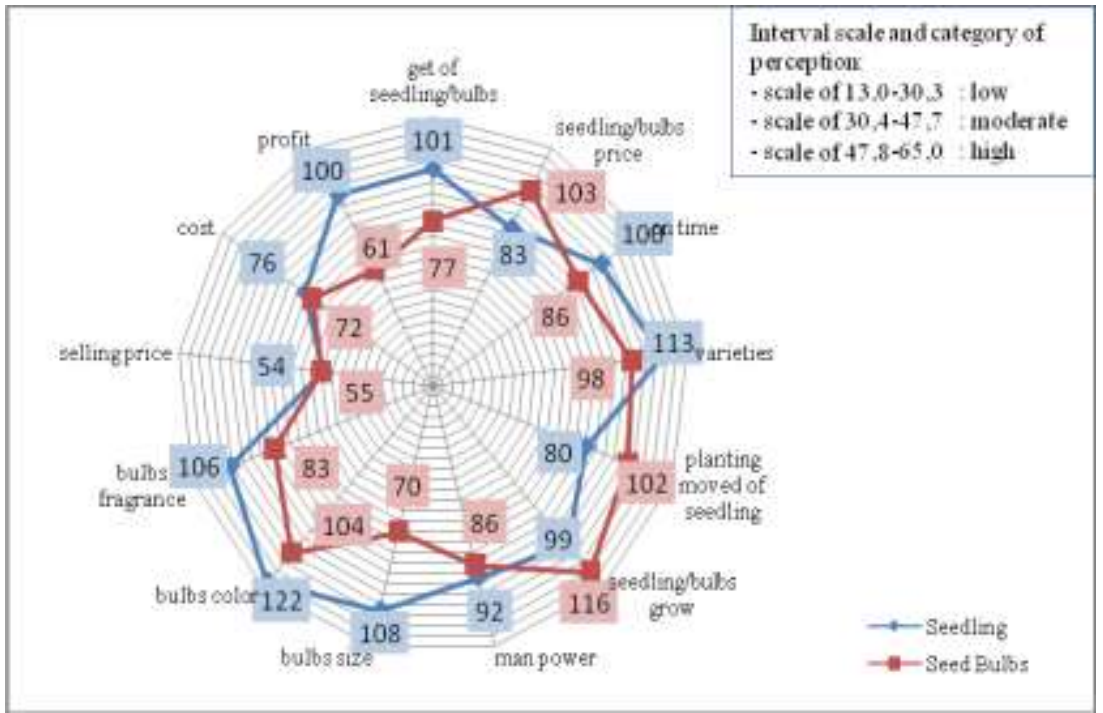

Fig. 1. Farmers' Perception of Shallot Farming in Padang Village, Tanggungharjo SubDistrict, Grobogan District, 2018

\subsubsection{Farmers' Perception of Seedling Shallot Farming Technology}

Farmers have a good perception of the technology of shallot seeds as planting material (seedling) on seven indicators, namely ease of obtaining seedling, timeliness of receiving seedling, the suitability of varieties, bulb size, bulb color, bulb aroma, and the potential benefits. High perception of the ease of getting seedling because surrounding markets sell True Shallot Seed (TSS). Therefore farmers can quickly get shallot seeds and sow instantly. In line with the opinion of [22], farmers in Grobogan District, especially in the Klambu Sub-District, have adopted TSS in shallot farming. [8] stated that farmers preferred seedling shallots due to their higher production. From the production side, farmers have a good perception of the size, color, and aroma of shallots obtained from seedling planting technology. The shallot bulbs are larger, with an average weight of 5 grams per bulb, redder bulb color, and sharper aroma.

Farmers have a moderate or ordinary perception of seedling shallot farming technology at the price of shallot seeds, ease of planting seeds, ease of growing seeds, and use of labor. The price of shallot seeds perceived by farmers is lower compare to the price of shallot bulbs. The price of TSS shallot seeds was IDR 2,000,000, and one hectare of land requires $3-7.5 \mathrm{~kg}$ of seeds. The cost of seeds per one hectare of land, therefore, range from IDR $6,000,000$ to IDR $15,000,000$. In contrast to the cost of seed bulbs which need as many as $1,200-1,500 \mathrm{~kg}$ for one hectare of land. At an average price of IDR 30,000, the seed bulbs cost will range from IDR $36,000,000$ to IDR 45,000,000. It means that there were as much as IDR 30,000,000 differences in the values of the two seeds. With the lower cost of purchasing seeds, farmers also have a high perception of the benefits received.

Shallot seeds sowing in a nursery is perceived common by farmers. Farmers' perceptions are in the medium criteria. Likewise, transferring seeds to the planting area is also commonly practiced by farmers. The use of labor in shallot farms using seeds is also perceived to be moderate. Although more workers are needed, since workers can quickly adapt and do the shallot seedling planting the time spent is not much different from seed bulbs planting. 
The main obstacle for farmers in shallot farming is in the selling price, which is often low in the harvest season. Farmers, therefore, have a low perception of the selling price of shallots. The selling price sometimes is only IDR 10,000 per kg. Farming costs are also perceived to be small by farmers. The farming costs incurred by farmers are relatively high so that if they are not getting reasonable selling prices, farmers will not benefit.

\subsubsection{Farmers' Perception of Shallot Farming Technology Using Seed Bulbs}

Bulbs shallot farmers only showed high perception in four indicators, namely expensive the price of shallot bulbs, shallot bulbs are easy to be planted and easy to grow, and the color of the shallot bulbs obtained. The farming analysis supports this result that the price of shallot bulbs is IDR 30,000 per $\mathrm{kg}$. At this price level, farmers consider that the price of shallot seed bulbs is rather high and is perceived as high by farmers.

Farmers had an average of 5 years of shallot farming experience. During this period, farmers had a good perception of the ease of planting shallot bulbs. The ease of growing bulbs is also perceived well by farmers. Farmers also stated good perception in the bright red color of the shallot bulbs.

Farmers stated moderate or ordinary perception on the ease of obtaining bulbs since farmers use the shallot seed bulbs in part from their harvest, so getting seed bulbs is common for farmers. [5] stated that farmers meet the needs of shallot seeds by producing their seeds. Farmers also perceive the usual timeliness to get seed bulbs because the seed is already available and planting shallots using tubers is more practical and has a higher success rate.

Since the seed bulbs derived from their harvest, the selection of varieties is also perceived as ordinary/medium perception by farmers since farmers have prepared varieties. Farmers only select the size of the seed bulbs. The aroma of shallots is also perceived as typical by farmers.

The use of labor in shallot farming is 100 days per planting season. The use of this labor is lower than the seedling shallot farming workers. Shallot seedling farmers transplant from seedbed to land, which requires more labors.

Low/unfavorable farmers' perceptions are obtained from indicators of farm costs, selling prices, bulbs sizes, and profits. Shallot farming requires a large amount of money, especially to buy seed bulbs and labor costs. From the analysis of farming costs, the proportion of the purchase of planting material and labor expenses reached $70.31 \%$ and $88.27 \%$ respectively of the total cost of shallot farming with seedling and seed bulbs. Based on the farming costs, farmers will consider the adequacy of expenditures to determine the planting size.

The size of bulbs is one of the quality criteria of shallot bulbs in addition to the aroma and color. In general, farmers prefer larger size bulbs than small bulbs. Poor perception of bulbs size is due to the smaller bulbs size obtained from shallot farming using bulbs compare to a seedling.

The sale price of shallot bulbs is perceived poorly (low perception) by farmers. The price of bulbs when farmers plant shallots were IDR 30,000 per $\mathrm{kg}$, while at harvest time farmers sold shallots at IDR 10,000 per $\mathrm{kg}$. Prices of agricultural products always change according to the conditions that occur so that prices are an important instrument for farmers in determining the behavior to sell or postpone selling their farm products [23; 24].

The price and yield largely determined farming profit. With a lower selling price than the purchase price, farmers have a low perception of the benefits of shallot farming planted with bulbs. Compared to the profitability of seedling shallot farming, the profit obtained by farmers of seed bulbs of shallot is lower because the yield obtained is also lower, which $5,880 \mathrm{~kg}$ compared to $32,000 \mathrm{~kg}$. The lower yield obtained by farmers who used seed bulbs 
of shallots was due to the continuous use of seeds and varieties. Decreasing yield and a large number of farming costs make the benefits received by farmers are not optimal, especially in low selling price conditions.

\subsection{Farmer's Preference for the Introduction of Seedling Shallot Farming Technology}

Farmers' preference for planting technology using shallot seedling was the basis for farmers to choose the most preferred type of technology. Table 4 present the level of farmers' preference for shallot farming technology using seedling.

Table 4. Farmers' Preferences of Shallot Farming Technology Using Seedling in Padang Village, Tanggungharjo Sub District, Grobogan District, 2018

\begin{tabular}{|c|l|r|r|r|}
\hline \multirow{2}{*}{ No } & \multicolumn{1}{|c|}{ Indicators } & \multicolumn{3}{|c|}{ Farmer Preferences (\%) } \\
\cline { 3 - 5 } & & Like & Doubted & Dislike \\
\hline 1. & Plant shallots with seeds & 73.33 & 20.00 & 6.67 \\
\hline 2. & Planting seed in seedbed & 73.33 & 23.33 & 3.33 \\
\hline 3. & More plants population & 70.00 & 20.00 & 10.00 \\
\hline 4. & The shape and size of the bulbs produced & 93.33 & 6.67 & 0.00 \\
\hline 5. & Amount of yield obtained & 93.33 & 6.67 & 0.00 \\
\hline 6. & Revenue obtained & 76.67 & 20.00 & 3.33 \\
\hline 7. & Introduction of seed planting technology & 83.33 & 13.33 & 3.33 \\
\hline
\end{tabular}

Source: Primary data (2018) (processed)

Farmers preferred almost all of the technology components of seedling shallots. The indicators were the level of preference for the shape and size of the bulbs produced from seedling planting technology and the amount of product obtained, which ranks first $(93.33 \%)$. These farmers' preferences by the yield of shallots in seedling planting technology 5.6 times compared to seed bulbs technology.

Of all respondents, $83.33 \%$ liked seedling planting technology and would apply the technology because of lower production costs and more yields, and 3.33\% would not apply seed planting technology due to its complexity in nursery making. One component of seedling shallots technology is seeded sowing in a nursery that requires more labor. Even so, farmers noted that technology has more yield. Farmers will get higher profits so that $83.33 \%$ of farmers respond well to the technological innovation of seedling shallots planting. Farmers knew the technique of planting shallots using seeds (TSS) in 2014, but not all farmers have applied the technology component because they are still doubts about the results $(20.00 \%)$.

\section{Conclusion}

Most of the shallot's farmers prefer to use seed bulbs since it is easier to plant. Demonstration plot of seedling technology of shallots with balanced fertilization was able to increase shallot yield more than four times, i.e. from 5,800 kilograms up to 32,580 kilograms per hectare. The introduction of technology also increased farmers' profits from IDR $11,549,000$ to IDR 239,044,100 per hectare. Therefore farmers' perception of shallot farming using seedling received a positive response to the ease and timeliness of obtaining seedling, the suitability of varieties, size, color, and aroma of the bulbs as well as the resulting profits.

Good perception of shallot farming using seed bulbs related to the price of expensive seed bulbs, ease of planting and ease of growing seed bulbs, and the color of the shallot obtained. The low perception of the farming systems relates to the selling price as well as 
the profitability of the farm because the selling price of shallots in most cases is lower than the purchase price of the seed bulbs. Those cause the profits obtained are lower. Farmers' preference (preference level) for shallot farming using seedling ranged from $73.33 \%$ 93.33\%. These indicate that farmers are ready to apply shallot farming using seedling.

Acknowledgment. High appreciation forwarded to the Indonesian Agricultural Research and Development Agency for funding provided through the collaborative program Collaborative Research, Assessment and Development of Strategic Agriculture of FY 2018 on the Study of Technology of Seed Shallot Technology Package to Support Production Achievement $>30$ Tons per Hectare in Central Java. We also thank Endah Winarni and Septi Lukitasari for their participation in the survey Padang Village, Tanggungharjo SubDistrict, Grobogan District.

\section{References}

1. BPS Indonesia. (2019)

2. BPS provinsi Jawa Tengah. (2019)

3. Tendaj, M., Krawiec, M., Palonka, S. \& Mysiak, B. Acta Sci. Pol. Hortorum Cultus 13, 5 (2014).

4. Roessali, W., Purbajanti, E. D. \& Dalmiyatun, T. IOP Conf. Ser. Earth Environ. Sci. 250 (2019).

5. Istiqomah, N., Barunawati, N., Aini, N. \& Widaryanto, E. J. Agric. Socio-Economic Sci. 6, 90 (2019).

6. Shimeles, A. J. Agric. Sci. 59, 2 (2014)

7. Khorasgani, O. A. \& Pessarakli, M. Adv. Plants Agric. Res. 9, 2 (2019)

8. Prahardini, P. E. R. \& Sudaryono, T. J. Pembang. dan Alam Lestari 9, 1 (2018).

9. Swastika, S., Yusuf, R. \& Istina, I. N. Proceeding of International Workshop and Seminar (2019)

10. Agung, I. G. A. M. S. \& Diara, I.W. Int. J. Environ. Agric. Biotechnol. 2, 6 (2017).

11. Rahayu, H. S. P., Muchtar \& Saidah. Asian J. Agric. 3, 1 (2019).

12. Susanawati, S., Masyhuri, M., Jamhari, J. \& Hadi Darwanto, D. Adv. Eng. Res. 172, (2018)

13. Rahayu, H. S. P., Yorobe, J. M. \& Quicoy, C. B. Int. J. Agric. Innov. Res. 7, 1 (2018).

14. Razzianto, D. A., Suminartika, E. \& Noor, T. I. Int. J. Adv. Sci. Technol. 29, 7 (2020).

15. Sahara, D., Chanifah \& Suwandi. J. Pengkaj. dan Pengemb. Teknol. Pertan. 20, 2 (2019)

16. Aldilah, R. Int. J. Educ. Humanit. Soc. Sci. 3, 2 (2020).

17. Fajarika, D., Fahadha, R. U., Mardiono, I. \& Miswari, N. J. Sci. Appl. Technol. 2, 1 (2019).

18. Benjamin, Y. F., Grace, O., Kwame, O. S. \& Payne, D. L. Agric. Commun. 5, 2 (2017)

19. Firmansyah, A. M., Liana, T. \& Bhermana, A. J. Agric. Sci. Food Res. 8, 4 (2017).

20. Palupi, E. R., Manik, F. \& Suhartanto, M. R. J. Trop. Crop Sci. 4, 1 (2017). 
21. Baloch, R. A., Baloch, S.U., Baloch, S.K., Baloch, H. N., Badini, S. A., Bashir, W., Baloch, A.B., \& Baloch, J. J. Econ. Sustain. Dev. 5, 24 (2014).

22. Pratiwi, P. R., Santoso, S. I. \& Roessali, W. Agrar. J. Agribus. Rural Dev. Res. 4, 1 (2018).

23. Salmiah, Sebayang, T., Sahir, S. H. \& Nadhilah, N. International Conference on Agriculture, Environment and Food Security. 454 (2020).

24. Erny, Darwanto, D. H., Masyhuri \& Waluyati, L. R. EurAsian J. Biosci. 13, (2019). 